\title{
Chemical Composition of Native Hazelnut (Corylus avellana L.) Varieties in Iran, Association with Ecological Conditions
}

\author{
Fatemeh Amini-Noori ${ }^{1}$ and Parisa Ziarati ${ }^{2 *}$ \\ ${ }^{1}$ Department of Food science \& Technology, Pharmaceutical Sciences Research Center, \\ Pharmaceutical Sciences Branch, Islamic Azad University, Tehran-Iran (IAUPS). \\ ${ }^{2}$ Department of Medicinal Chemistry, Pharmaceutical Sciences Branch (IAUPS), \\ Islamic Azad University, Tehran, Iran.
}

DOI: http://dx.doi.org/10.13005/bbra/1873

(Received: 19 October 2015; accepted: 20 November 2015)

\begin{abstract}
According to statistics of FAO, in Iran 19500 hectares the hazelnut, 18000ton produced annually, and $923 \mathrm{~kg}$ is mean production for every hectare. There are some genotypes of hazelnut that their growing areas are limited to Gilan, Aredbil, Mazandaran, Golestan and Qazvin Provinces in Iran which are on the shores of the Caspian Sea. Varieties, location, composition of soils, usage of fertilizer and irrigation affect the fatty acid, mineral and vitamin composition of hazelnuts, and consequently influence the nutritional value and quality of the product. Hazelnut (Corylus avellana L.) samples were collected during the during the 2015 harvest season (Harvest was performed during the late August) from 12 different distinguished cultivars of trees grown in a replicated trial in an experimental orchard at Tarem ( zanjan province ) and Rudsar ( Gilan Province) county farmlands County farmlands as two economically important provinces. All trees under the study were of seedlings origin and are growing naturally and treating traditionally. The order depending on the contents of elements $(\mathrm{mg} / 100 \mathrm{~g})$ in kernel of $C$. avellana samples in Rudsar studied regions was: $\mathrm{K}>\mathrm{P}>\mathrm{Ca}>\mathrm{Mg}>\mathrm{Fe}>\mathrm{Mn}>\mathrm{Zn}>\mathrm{Cu}>$ $\mathrm{Na}>\mathrm{Se}>\mathrm{Li}$ whereas in Tarem farmlands the order is: : $\mathrm{K}>\mathrm{P}>\mathrm{Mg}>\mathrm{Ca}>\mathrm{Fe}>\mathrm{Cu}>\mathrm{Mn}>$ $\mathrm{Zn}>\mathrm{Na}>\mathrm{Se}>\mathrm{Li}$ which shows that high levels of these elements in the soil of area, have a great impact on the highness of Potassium and Phosphorous and Magnesium in the fruits. In the Rudsar variety, total MUFA was found as $87.048 \%$. In both varieties after oleic acid, stearic acid, linolaidic acid, Butyric acid and palmitic acid contents were followed.
\end{abstract}

Keywords: Hazelnut Kernel, (Corylus avellana L.), Chemical Composition , Mineral Elements, Iran

Hazelnut (Corylus avellana L.) is a shrub of Betulaceae family and its fruit is one of the important nut crop in the world ${ }^{1}$. In 2012, among the worldwide production of tree nuts, hazelnuts represented the sixth most relevant culture and occupied the fourth place, in terms of global trade, just behind pistachios, almonds and cashew nuts ${ }^{2}$.

It is mainly distributed along the coasts

\footnotetext{
* To whom all correspondence should be addressed. Tel: +98-21-22600037; Fax: +98-21-22633986; E-mail: Ziarati.p@iaups.ac.ir
}

of the Black Sea region of Turkey, southern Europe (Italy, Spain, Portugal and France), and in some areas of the United States (Oregon and Washington). Hazelnut is also grown in New Zealand, China, Azerbaijan, Kirgizstan, Georgia and Iran. Turkey is the world's largest producer of hazelnut, followed by Italy, USA ${ }^{3}$.

According to statistics of FAO, in Iran 19500 hectares the hazelnut, 18000ton produced annually, and $923 \mathrm{~kg}$ is mean production for every hectare $^{4}$. There are more genotypes of hazelnut in iran such as Garche, Shastak, Paeezeh, Mahali, Karaj, Tabestaneh, Rasmi, Shirvani, Pashmineh ${ }^{5}$. 
Hazelnut growing areas of Iran are limited to Guilan, Aredbil, Mazandaran, Golestan and Qazvin Provinces, whichare on the shores of the Caspian $\mathrm{Sea}^{6}$ and have high rainfall and high relative humidity (RH). Hazelnut prefers subtropical climates with high relative humidity (75-80\%). It grows better in areas where the annual average temperature is $13-14^{\circ} \mathrm{C}$, the average temperature in the coldest month is not more than $3.5-5.5^{\circ} \mathrm{C}$, the average temperature in the warmest month reaches $22-23^{\circ} \mathrm{C}$, and annual rainfall is $1500-2000 \mathrm{~mm}$ (900$1200 \mathrm{~mm}$ during the growth period) $)^{7}$. Nuts are nutrient dense foods rich in unsaturated fatty acids (PUFAs and MUFAs) and other nutritional compounds such as protein, carbohydrate, fiber and minerals. Nuts are highly beneficial to human health because of their unique composition ${ }^{8-9}$. Epidemiologic studies have indicated that nut consumption associated with a reduced incidence of coronary heart disease, gallstones and diabetes. Different researches suggest beneficial outcomes on cancer, hypertension, oxidative stress, inflammation, vascular reactivity, Blood pressure, visceral adiposity and the metabolic syndrome [1011]. Hazelnut kernels are consumed as natural, blanched and roasted or their products, such as pastry and chocolate industry. Hazelnut also add flavor and texture to bakery, confectionery, cereal, salad, ice cream, nougat, cookie, snacks, butter, oil, sauce dairy, and dessert formulation ${ }^{2-3-12-13}$. Hazelnut skin offers potential for utilization as a coloring agent in foods with its natural brown color $^{12}$. As a consequence, hazelnuts along with other tree nuts play an important role in economy since they are a significant part of the human food supply ${ }^{2}$.

Hazelnuts in Europe are considered a widespread cause of food allergies among both children and adults. Therefore the diversity of processed foodstuffs containing hazelnuts is a potential hazard tot allergic in some of humans ${ }^{14}$. Nut and kernel size, nut and kernel shape, percent kernel, shell thickness, low kernel defect, protein and high content of fatty acids are among the main characteristics considered in the evaluation of nut and kernel quality in hazelnut ${ }^{15}$.

Potassium (K), phosphorus (P), magnesium $(\mathrm{Mg})$ and iron $(\mathrm{Fe})$ are found in significant quantities in the nuts [16]. Calcium (Ca), sodium $(\mathrm{Na})$, zinc $(\mathrm{Zn})$ and Copper $(\mathrm{Cu})$ also exist modestly ${ }^{16-17}$. Iron (Fe) is an element in hemoglobin, myoglobin, and a large number of enzymes; therefore it is an essential mineral in daily diet ${ }^{18-19}$. About 2\% of total body weight of human body is consisted of Calcium. Calcium (Ca) is the major component of bone and assists in teeth development ${ }^{17,20-21}$. Potassium $(\mathrm{K})$ is the third most abundant mineral in human body which is acting as an electrolyte. This mineral is needed for keeping heart, brain, kidney, muscle tissues and other important organs of human body in good state $e^{6,16}$. Zinc (Zn), a constituent of enzymes involved in most major metabolic pathways, is an essential element for plants, animals, and humans ${ }^{18}$. Water and soil of the cultivation regions have an important role on quality and quantity of micronutrient compounds (such as minerals, vitamins, fatty acids and amino acids) in walnut. The geographical conditions affect the nutritional value of walnuts ${ }^{22}$.

Varieties, location, composition of soils, usage of fertilizer and irrigation affect the fatty acid, mineral and vitamin composition of hazelnuts, and consequently influence the stability and quality of the product ${ }^{23}$. Hazelnuts are rich in polyunsaturated fatty acids, and essential for human health ${ }^{24-26}$. Hence, the objective of this study is to determine the chemical composition of different hazelnut varieties growing in Iran.

\section{MATERIALANDMETHODS}

\section{Sampling Methods}

Hazelnut (Corylus avellana L.) samples were collected during the during the 2015 harvest season (Harvest was performed during the late August) from 12 different distinguished cultivars of trees grown in a replicated trial in an experimental orchard at Tarem ( zanjan province ) and Rudsar ( Gilan Province) county farmlands.

\section{Study Area}

Tarom farms in Zanjan province have the highest acreage under hazelnut cultivation. The experimental field was located in a 320 hectare irrigated hazelnut orchard located in Tarom region, of Zanjan Province in Iran (between $48^{\circ} 562$ and $50^{\circ} 52 \mathrm{E}$; and $36^{\circ} 472$ and $37^{\circ} 362 \mathrm{~N}$ ). Another area of hazelnut sampling was Rudsar which situated in Gilan, Iran. Its geographical coordinates are $37^{\circ}$ 34 ' 12 “ North, $49^{\circ} 9^{\prime}$ ' 53" East ( figure 1). 


\section{Oil (Lipid) Content}

The lipid contents of five grams of hazelnut kernel by petroleum ether in a Soxhlet apparatus were extracted. The weight of the lipid obtained after evaporating off the petroleum ether from the extracts gave the weights of the crude fat in the samples ${ }^{27-28}$.

\section{Zinc, Manganese, Copper and Potassium} Determination

For Zinc, Manganese, Copper and Selenium concentration hazelnut kernel samples were dried in oven for 68-72 hours at a temperature of $85^{\circ} \mathrm{C}$. The samples were then ground and sieved through $0.5 \mathrm{~mm}$ sieve. The powdered samples then subjected to the acid digestion using nitric acid (65\% Merck, Germany), Sulfuric acid (96.5\% Merck, Germany) and perchloric acid (70\% Sigma- Aldrich). Two gram of air-dried of each homogeneously hazelnut kernel samples accurately weighed and $20.0 \mathrm{~mL}$ of the digestion mixture (3 parts by weight of concentrated nitric acid: 2 parts of concentrated Sulfuric acid $\& 3$ parts by weight concentrated perchloric acid) and heated slowly by an oven and then rise the temperature. The remaining dry inorganic residues were dissolved in $25.0 \mathrm{~mL}$ of nitric acid and the solution used for the determination of mineral elements. Blanks and samples were also processed and analyzed simultaneously. All the chemicals used were of analytical grade (AR). Standardized international protocols were followed for the preparation of material and analysis of heavy metals contents ${ }^{29-}$ ${ }^{35}$. The samples were analyzed by Flame Emission Spectrophotometer Model AA-6200 (Shimadzu, Japan) using an air-acetylene flame, using at least five standard solutions for each metal and determination of potassium content was followed by FDA Elemental analysis ${ }^{34}$ ( Ora Laboratory Manual, 2013). Also, periodic testing of standard solutions was performed in order to verify of reliability of the measuring apparatus. The accuracy was checked using quality control test for fungi and their substrate samples to show the degree of agreement between the standard values and measured values; the difference was less than $5 \%$. The samples were analyzed by Flame Emission Spectrophotometer Model AA6200 (Shimadzu, Japan) using an air-acetylene, flame temperature: $2800^{\circ} \mathrm{C}$, acetylene pressure:
0.9-1.0 bar, air pressure: $4.5-5$ bar, reading time: 1-10 sec (max $60 \mathrm{sec}$ ), flow time: 3-4 sec (max 10 sec).

\section{Iron Determination}

The aliquot was passed through the atomic absorption spectrophotometer to read the iron concentration. Standards were prepared with a standard stock of $10 \mathrm{mg} / \mathrm{L}$ using ferrous ammonium sulphate where 3 - $60 \mathrm{ml}$ of iron standard solution $(10 \mathrm{mg} / \mathrm{L})$ were placed in stepwise volumes in $100 \mathrm{ml}$ volumetric flasks. $2 \mathrm{ml}$ of hydrochloric acid were added and then brought to the volume with distilled water. The concentration of iron in the aliquot was measured using the atomic absorption spectrophotometer in $\mathrm{mg} / \mathrm{L}$. The whole procedure was replicated three times.

Calcium, Sodium and Magnesium Determination

The contents of $\mathrm{Ca}, \mathrm{Mg}$ and $\mathrm{Na}$ in hazelnut kernels were measured by atomic absorption spectrophotometer (AAS) (Model AA6200 Shimadzu, Japan) according to the method of Hernandez $^{36-37}$. A 5 g sample was placed in a previously weighed porcelain crucible and heated. The resulting white ash was weighed, dissolved in $12 \mathrm{ml}$ of concentrated nitric acid, percholoric (3:2) and diluted with nitric acid $10 \%$ in a $25 \mathrm{ml}$ calibrated flask. The solution then was used to determine $\mathrm{Ca}$, $\mathrm{Na}$, and Mg. Standard stock solution of sodium, magnesium and calcium was prepared from AAS grade chemicals (Merck, Germany) by appropriate dilution.

\section{Selenium Determination}

Stock standard solutions for selenium were $1000 \mathrm{~g} / \mathrm{mL}$ solution. All reagents and standards were of analytical grade ( Merck, Germany).The palladium matrix modifier solution was prepared by the dilution $(10 \mathrm{~g} / \mathrm{L}) \operatorname{Pd}\left(\mathrm{NO}_{3}\right)_{2}$ and iridium AA standard solution, $1000 \mathrm{~g} / \mathrm{mL}$ in $20 \% \mathrm{HCl}, 0.1 \% \mathrm{~V} / \mathrm{V}$ nitric acid prepared by dilution trace pure $65 \%$ nitric acid and $0.1 \%$ Triton X-100 were used. Doubly distilled water was used in all operations. The samples were analyzed by Flame Emission Spectrophotometer Model AA-6200 (Shimadzu, Japan). The analyze performed according by Analytical Method ATSRD ${ }^{38-40}$.

\section{Fatty Acid Determination}

Determination of Fatty acid composition for hazelnut samples were done by using a modified fatty acid methyl ester method as described by $\mathrm{Hisi}^{41-44}$. The oil was extracted three times for $2 \mathrm{~g}$ 
air-dried seed sample by homogenization with petrolium ether. The oil samples (50-100 mg) were converted to its fatty acid methyl esters (FAME). The methyl esters of the fatty acids (1 ìl) were analyzed in a gas chromotography (Shimadzu GC2011) equipped with a flame ionizing detector (FID), a fused silica capillary column ( $60 \mathrm{~m}$ x $0.25 \mathrm{~mm}$ i.d.; film thickness 0.20 micrometer).

\section{Statistical analyses}

All the data were analyzed using the SPSS 20 statistical software for analysis of variance using ANOVA and Duncan's least significant difference (LSD at $\mathrm{p}<0.05$ ) for statistical significance. 3 duplicates with a replicate were considered in this research, and data was reported as the mean \pm standard error of the mean.

\section{RESULTSAND DISCUSSION}

Literally, the kernels contain many kinds of essential and mineral elements; Phosphor, Potassium, magnesium, and calcium were the major elements. The mean content of mineral elements (mg/100 g DW): Sodium, Selenium, Calcium, Iron, Magnesium, Copper and Zinc in the Persian Persian Hazelnut (Corylus avellana L.) samples are shown in Table 1 . The samples were analyzed by wet digestion method and standardized international protocols were followed for the preparation of material and analysis of heavy metals contents and analyzed by Atomic Absorption
Spectrophotometer in Research Laboratory in Pharmaceutical Sciences Branch, Islamic Azad University.

Due to historical surveys hazelnut is considered as a good source of dietary miner-als among common foodstuffs. Hazelnut almost contains high quantities of minerals, especially potassium and phosphor, which are present much higher in Rudsar samples than Tarem population in this study. Potassium, Calcium, Iron, magnesium and Phosphor were found in significant quantities in these studied nuts (Fig. 2).

In investigation on these two varieties, the highest fatty acid had oleic acid with $85.026 \%$ in Rudsar ( Gilan) and 83.226\% in Tarem samples. After oleic acid, stearic acid, linolaidic acid, Butyric acid and palmitic acid contents were followed as $7.152 \%, 1.798 \%, 0.133$ and $0.055 \%$, respectively in Rudsar variety. In this variety, total MUFA was found as $87.048 \%$ although total SFA and total PUFA (Polyunsaturated Fatty Acid) were found as $15.599 \%$ and $1.869 \%$, respectively (Table 2).In Tarem variety the order of fatty acids are the same while their levels showed significantly differences. The total PUFA in Tarem samples was found $2.846 \%$.

The oil contents of kernels changed among the location of farmlands to more than about $67 \%$ of each. However, because of economic value of the oil, these kernels could be used as potential sources of oils. Rudsar cultivars had more oil and

Table 1. The mean content of mineral elements (mg/100 g Dry Weight) in studied Persian Hazelnut

\begin{tabular}{lccc}
\hline Minerals & $\begin{array}{c}\text { Mean content of } \\
\text { elements in 100 Rudsar } \\
\text { samples } \pm \mathrm{SD}^{*}(\mathrm{mg} / 100 \mathrm{~g})\end{array}$ & $\begin{array}{c}\text { Mean content of elements } \\
\text { in } 100 \text { Tarem samples } \\
\pm \mathrm{SD}^{*}(\mathrm{mg} / 100 \mathrm{~g})\end{array}$ & $\begin{array}{c}\text { Mean Content of Persian } \\
\text { Hazelnut samples } \pm \mathrm{SD}^{*} \\
(\mathrm{mg} / 100 \mathrm{~g})\end{array}$ \\
\hline $\mathrm{Na}$ & $3.01 \pm 0.023^{\mathrm{a}}$ & $3.26 \pm 0.054^{\mathrm{a}}$ & $3.14 \pm 0.038$ \\
$\mathrm{~K}$ & $1036 \pm 10.22^{\mathrm{a}}$ & $1011 \pm 25.06^{\mathrm{b}}$ & $1023 \pm 17.64$ \\
$\mathrm{Ca}$ & $204.67 \pm 9.27^{\mathrm{a}}$ & $215.11 \pm 8.34^{\mathrm{a}}$ & $209.89 \pm 8.80$ \\
$\mathrm{Mg}$ & $203.47 \pm 10.32^{\mathrm{b}}$ & $244.21 \pm 8.37^{\mathrm{a}}$ & $223.84 \pm 9.34$ \\
$\mathrm{Fe}$ & $39.54 \pm 1.44^{\mathrm{b}}$ & $45.22 \pm 6.87^{\mathrm{a}}$ & $42.38 \pm 4.16$ \\
$\mathrm{Cu}$ & $3.14 \pm 0.02^{\mathrm{b}}$ & $8.74 \pm 0.23^{\mathrm{a}}$ & $5.94 \pm 0.12$ \\
$\mathrm{Se}$ & $0.002 \pm 0.001^{\mathrm{a}}$ & $0.004 \pm 0.002^{\mathrm{a}}$ & $0.003 \pm 0.0015$ \\
$\mathrm{Mn}$ & $10.40 \pm 0.62^{\mathrm{a}}$ & $7.23 \pm 1.28^{\mathrm{b}}$ & $8.82 \pm 0.95$ \\
$\mathrm{Zn}$ & $3.22 \pm 0.13^{\mathrm{b}}$ & $6.78 \pm 0.56^{\mathrm{a}}$ & $5.00 \pm 0.34$ \\
$\mathrm{Li}$ & $0.001 \pm 0.001^{\mathrm{a}}$ & $0.002 \pm 0.001^{\mathrm{a}}$ & $0.0015 \pm 0.001$ \\
$\mathrm{P}$ & $344.23 \pm 11.23^{\mathrm{a}}$ & $306.78 \pm 10.44^{\mathrm{b}}$ & $325.50 \pm 10.84$ \\
\hline
\end{tabular}

${ }^{*} \mathrm{SD}=$ Standard Deviation 
AMINI-NOORI \& ZIARATI, Biosci., Biotech. Res. Asia, Vol. 12(3), 2053-2060 (2015)

Table 2. Fatty acid composition of Hazelnut populations oils (\%)

\begin{tabular}{lcc}
\hline \multicolumn{3}{c}{ Hazelnut populations } \\
Fatty Acids & Rudsar & Tarem \\
\hline Butyric acid (C4:0) & $0.133 \pm 0.011^{\mathrm{b}}$ & $0.201 \pm 0.024^{\mathrm{a}}$ \\
Myristic acid (C14:0) & $0.028 \pm 0.021^{\mathrm{a}}$ & $0.039 \pm 0.003^{\mathrm{b}}$ \\
Pentadecanoic acid (C15:0) & $0.004 \pm 0.002^{\mathrm{a}}$ & $0.004 \pm 0.001^{\mathrm{a}}$ \\
Oleic acid (C18:1,c) & $85.026 \pm 2.008^{\mathrm{a}}$ & $83.226 \pm 2.018^{\mathrm{b}}$ \\
Palmitic acid (C16:0) & $0.055 \pm 0.033^{\mathrm{a}}$ & $0.048 \pm 0.039^{\mathrm{a}}$ \\
Stearic acid (C18:0) & $7.152 \pm 2.008^{\mathrm{b}}$ & $7.830 \pm 2.003^{\mathrm{a}}$ \\
Linoelaidic acid (C18:2t) & $1.798 \pm 1.182^{\mathrm{a}}$ & $1.546 \pm 1.222^{\mathrm{b}}$ \\
SFA (Saturated fatty acid) & $15.599 \pm 2.026^{\mathrm{a}}$ & $15.056 \pm 1.989^{\mathrm{a}}$ \\
MUFA (Monounsaturated fatty acid) & $87.048 \pm 1.524^{\mathrm{a}}$ & $80.598 \pm 1.932^{\mathrm{b}}$ \\
PUFA (Polyunsaturated fatty acid) & $1.869 \pm 0.198^{\mathrm{b}}$ & $2.846 \pm 0.193^{\mathrm{a}}$ \\
SFA/MUFA (\%) & $17.920 \pm 2.928^{\mathrm{a}}$ & $18.680 \pm 2.656^{\mathrm{a}}$ \\
SFA/UFA (Unsaturated fatty acid (\%) & $11.777 \pm 2.674^{\mathrm{b}}$ & $17.554 \pm 2.678^{\mathrm{a}}$ \\
\hline
\end{tabular}

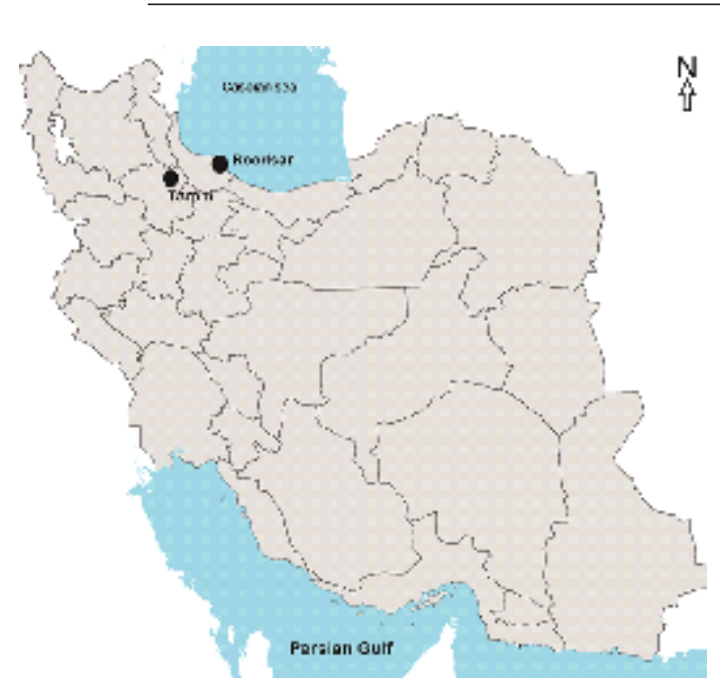

Fig. 1. Description of Hazelnut sampling

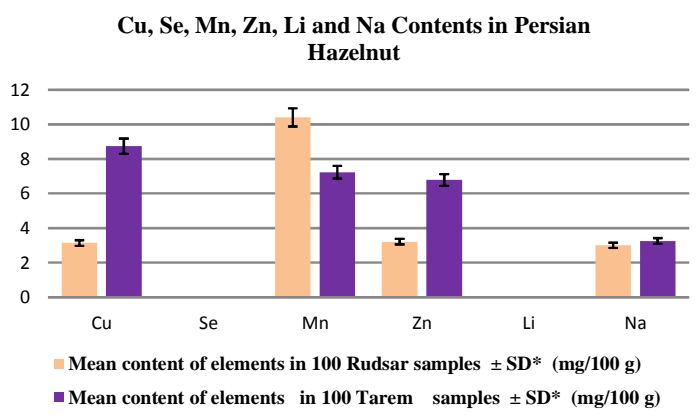

Fig. 3. Proximate composition and essential mineral contents in Persian Hazelnut

(Corylus avellana L.) orchards kernel samples

according to variance analyses, differences between hazelnut cultivars to fatty acid contents were found statistically important at $\mathrm{p}<0.01$ level.

\section{CONCLUSION}

A significant positive correlation (0.817)

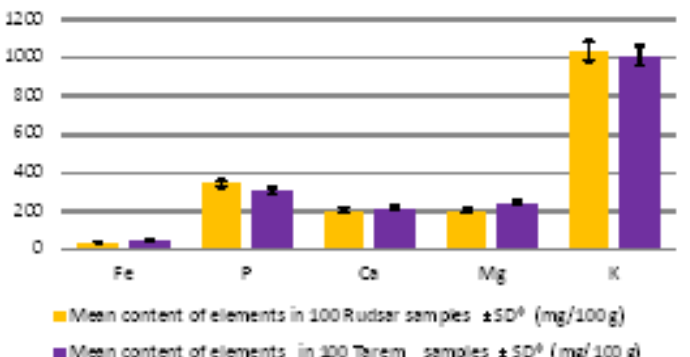

Fig. 2: Proximate composition and mineral contents in Persian Hazelnut

(Corylus avellana L.) orchards kernel samples

between nut weight and kernel weight was observed in this study which is as reported by other researchers, but no relationship between nut weight and kernel ratio $(P \leq 0.05)$ was found. Shell thickness showed a negative correlation (-0.626); however, nut weight showed a positive correlation $(+0.402)$ with shell thickness (P d"0.01). This means that heavier nuts have thicker, heavier shells. In conclusion, evaluation of 420 hazelnut seedling samples reveals that they could be not only very 
promising raw materials for various industries but also would serves as useful dietary supplements. The high protein and oil values of the kernels and high levels of mineral elements indicate their potentials usefulness in human animal and poultry feed supplements hazelnut kernel oil can also be recommended for cosmetics industries due to and for Anti-Aging, Moisturizing, Regenerative \& Toning Properties and these kernels should not be overlooked anymore in pharmaceutical technology.

The oil contents of hazelnuts were in the range of $51.4 \%$ to $75.1 \%$ of dried weight of the kernel. Combining the nut yield, percent kernel and oil content of the kernel. The hazelnut oils were unique in that only two fatty (oleic and linoleic) acids accounted for $90 \%$ of their fatty acid content. High oleic and linoleic acids contents and low linolenic acid content improved the oils thermo oxidative stability, while low levels of saturated (palmitic and stearic) acids enhanced their properties in cold environments.

\section{ACKNOWLEDGEMENT}

Financial Supports from Pharmaceutical Sciences Branch, Islamic Azad University (IAUPS) is gratefully acknowledged.

\section{REFRENCES}

1. Sabeti, H. Jungles, trees and shrub in Iran (fourth edition). Yazd University press, 2006; 806.

2. Costa, J., Ansari, P., Mafra, I., Oliveira, P.P. M.B. , Baumgartner, S. Development of a sandwich ELISA-type system for the detection and quantification of hazelnut in model chocolates. Food Chemistry, 2015; 173: 257-265.

3. Rezaei, F., Bakhshi, D., F.Ghazvini1, R., J.Majd, D. , Pourghayoumi, M.R. Evaluation of fatty acid content and nutritional properties of selected native and imported hazelnut (Corylus avellana L.) varieties grown in Iran. Journal of Applied Botany and Food Quality, 2014; 87:104107.

4. Hussein zadeh, M.K., piraivat lou, P., Imani, S. A. Investigation the Phonological and Morphological traits of the some superior genotype of hazelnut in Talesh region of Guilan province. International Journal of Nuts and Related Sciences, 2011; 2(3): 41-46.

5. Hosseinava, S., Razavi, V., Keshavarzi, M. \&
Javadi, D. Morphological Diversity of some Iranian Local Hazelnut(Corylus avellana) Genotypes in Climatical Conditions of Karaj. Seed AND Plant Improvement Journal, 2012; 28(4):579-592.

6. Hoseinova, S., A. Imani, Makhnov, A. Investigation of percentage of dicogamy and selection of best pollinizer for commercial varieties of hazelnut. Iranian J. Agric. Sci., 2006; 37: 371-380.

7. Mirotadze, N., V. Gogitidze, N. Mikadze, L. Goginava, Mirotadze, M. Agro-ecological zones of hazelnut in Georgia. Acta Hort., 2009; 845: 291-294.

8. Ros, E. Health benefits of nut consumption. Nutrients.2010; 2(7): 652-82.

9. Sabate, J., Fraser, G., Burke, K., Knutsen, S., Bennett, H., Lindsted, K. Effects of walnuts on serum lipid levels and blood pressure in normal men. N. Engl. J. Med. , 1996; 328: 603-607.

10. Sabate, J., Salas, J., Ros, E. Nuts, nutrition and health outcomes. Br. J. Nutr. X., 1996; 96: 1102.

11. Sabate, J., Angt, Y. Nuts and health outcomes, new epidemiologic evidence. Am. J. Clin,.Nutr, 2009; 89: 1643-1648.

12. Ko“ksal, A.I., Artik, N., Simsek, A., Gunes,N. Nutrient composition of hazelnut (Corylus avellana L.) varieties cultivated in Turkey. Food Chemistry, 2006; 99: 509-515.

13. Özdemir, S.K., Yýlmaz, C., Durmaz, G. , Gökmena, V. Hazelnut skin powder: A new brown colored functional ingredient. Food Reaserch Inrenational, 2014; 65: 291-297.

14. Wigotzki, M., Steinhart, H \& Paschke, A. Determination of the allergenicity of various hazelnut products by immunoblotting and enzyme allergosorbent test inhibition. Journal of Chromatography B., 2001; 756: 239-248.

15. Balta, M., Yarilgac, T., Askin, M., Kucuk, M., Balta, F., Özrenk, K. Determination of fatty acid compositions, oil contents and some quality traits of hazelnut genetic resources grown in eastern Ana-tolia of Turkey. J. Food Compos. Anal., 2006; 19: 681-686.

16. Cosmulescu, S., Baciu, A., Achim, Gh., Botu, M., Trandafir, I. Mineral Composition of Fruits in Different Walnut (Juglans regia L.) Cultivars. Notulae Botanicae Horti AgrobotaniciClujNapoca. ., 2009; 37: 156-160.

17. Siahnouri, Z., Sadeghian, M., Salehisormghi, M., Qomi, M. Determination of Iranian Walnut and Pistachio Mineral Contents. Journal of Basic and Applied Scientific Research. 2013; 3: 217220.

18. Ozkutlu, F., Dogru, Y., Ozenc, Yazici, G. The 
importance of Turkish hazelnut trace and heavy metal contents for human nutrition. Journal of Soil Science and Environmental Management. 2011; 2: 25-33.

19. Grace, M. H., Warlick, Ch. W., Neff, S. A., Lila, M. A . Efficient preparative isolation and identification of walnut bioactive components using high-speed counter-current chromatography and LC-ESI-IT-TOF-MS. Plants for Human Health Institute, Food Bioprocessing and Nutritional Sciences. ,2014; 158 : 229-238.

20. AOAC. Official Methods of Analysis, 14th Ed., Assoc. Offic. Anal. Chem., Arcingten, VA 1984: 22. AOAC. Association of Official Analytical Chemist Official Method of Analysis. 1984. 14th ed edited by William Harwite and Sidney Williams respectively, Washington DC USA.

21. AOACS, 1990 . Official Methods and Recommended Practices. Vol. 1, 4th Ed. American Oil Chemists Society, Champaign, II.

22. Aryapak, S., Ziarati, P. Nutritive Value of Persian walnut (Juglans regia L.) orchards. American Eurasian J. Agric. \& Environ. Sci., 2014; 14 (11): 1228-1235.

23. Ackurt, F., Ozdemir, M., Biringen, G., Loker, M. Effects of geographical origin and variety on vitamin and mineral composition of hazelnut (Corylus avellana L.) varieties cultivated in Turkey. Food Chem., 1999;65: 309-313.

24. Garcia, J.M., Agar, I.T. , Streif, J. Lipid characteristics of kernels from different hazelnut varieties. Turkish J. Agric. For., 1994; 18: 199202.

25. Pala, M., Ackurt, F. , Loker, M., Yildiz , M. , Emiroglu, S. Chemical composition of some hazelnut varieties and evaluation on nutritional physiology. Turkish J. Agric. For., 1996; 20: 43-48.

26. Alphan, E., Pala, M., Ackurt ,F., Yilmaz, T. Nutritional composition of hazelnuts and its effects on glucose and lipid metabolism. Acta Hortic., 1997; 445: 305-310.

27. AOAC. 2000 .Association of Official Analytical Chemist Official Method of Analysis. 14th ed edited by William Harwite and Sidney Williams respectively, Washington DC USA.

28. Akpabio, U. D. Evaluation of proximate composition, mineral element and anti- nutrient in almond (Terminalia catappa) kernels”. Pelagia Research Library ,Advances in Applied Science Research, 2012; 3: 2247-2252. Available online at www.pelagiaresearchlibrary.com .

29. Meeker, E. W., Wagner, E. C. Titration of ammonia in presence of boric acid.” Ind Eng Chem, Anal Ed. 1933 ; 5: 396-398.
30. Wagner, E.C. Titration of ammonia in the presence of boric acid in the macro-,semimicroand micro-Kjeldahl procedures with methyl red indicator and the color-matching end point”. Ind Eng Chem, Anal Ed. 1940 ;12: 771-772.

31. Ziarati, P., Rabizadeh, HSafety and Nutritional Comparison of Fresh, Cooked and Frozen Mushroom (Agaricus bisporus).” Intl J Farm \& Alli Sci., 2013; 2: 1141-1147. Available in Site: http://ijfas.com/wp-content/uploads/2013/12/ 1141-1147.pdf.

32. Ziarati, P., Azizi, N. Chemical Characteristics and Mineral Contents in Whole rice grains, Hulls, Brown rice, Bran and Polished Ali Kazemi Rice in Gilan province - North of Iran”. Intl J Farm \& Alli Sci. 2013; 2 : 1203-1209. Available in Site: http://ijfas.com/wp-content/uploads/ 2013/12/1203-1209.pdf.

33. Ziarati, P., Rabizadeh, H. The Effect of Thermal and Non Thermal of Food Processes and Cooking Method in Some Essential Mineral Contents in Mushroom ( Agaricus bisporus) in Iran. J. Nov. Appl Sci., 2013; 2: 954-959. Available in site: http://jnasci.org/wp-content/ uploads/2013/11/954-959.pdf.

34. AOAC .1998. Association of Official Analytical Chemists. Wet digestion for non-volatile metals in: AOAC official methods of analysis, 16th edition, 4th revision, vol.1,chapter 9.

35. Ziarati, P. Determination of Contaminants in Some Iranian Popular Herbal Medicines. $J$ Environ Analytic Toxicol., 2012; 2: 120. 2012.doi:10.4172/2161-0525.1000120.

36. Ziarati, P., Tosifi. S. Comparing some physical and chemical properties of green olive (Olea europea $L$.) In Iran association with ecological conditions. IJPAES, . 2014; 4: 519-528.

37. ORA Laboratory Manual FDA Office of Regulatory Affairs Office of Regulatory Science. Vol 6. Document No.: Iv-02, Version No.: 1.5, Effective Date: 10-01-03 Revised: 02-14-13. Available in Site: http://www.fda.gov/ downloads/ScienceResearch/FieldScience/ UCM092226.pdf.

38. Masamba, K.G., Kazombo-Mwale, R. Determination and comparison of nutrient and mineral contents between cultivated and indigenous edible mushrooms in Central Malawi. African Journal of Food Science., 2010; 4: 176179. Available in Site: http:// www.academicjournals.org/ajfs.

39. Hernandez, O.M., Fraga, J.M.G., Jimenez, A.I., Jimenez, F.,Arias ,J.J. Characterization of honey from the Canary Islands: determination of the mineral content by atomic absorption spectrophotometer. J Food Chem, 2004; 93: 449- 
458.

40. Agency for Toxic Substance and Disease Registry (ATSDR) .1996. Toxicological Profile for Selenium (Update). US Department of Health and Human Services.

41. Héél, Y., Instrumental Analysis Techniques, Ege Univ. Engineer Fac. Publ. 1998; 55: BornovaÝzmir. (in Turkish) .

42. ÖZCAN, M. M. Some Nutritional Characteristics of Fruit and Oil of Walnut (Juglans regia L.) Growing in Turkey. Iran. J.
Chem. Chem. Eng. , 2009; 28: 57-62.

43. Zarei, M., Asgarpanah, J., Ziarati, P. Chemical Composition Profile of wild Acacia Oerotofa ( Forssk) Schweinf Seed Growing wild in the south of Iran. Oriental Journal of Chemistry. 2015; 31(4).

44. Abbasian, K., Asgarpanah, J., Ziarati, P. Chemical Composition profile of Acacia nilotica Seed Growing Wild in South of Iran. Oriental Journal of Chemistry. 2015; 31(3): 1027-1033. 